\title{
Assessment of Medication Use by Publics in Sulaimani Province
}

\author{
Kamal Aziz Enayat \\ Community Health \\ Technical College of Health \\ Sulaimani Polytechnic University \\ Sulaimani, Iraq \\ Kamal.aziz@gmail.com
}

\author{
Mariwan Abdulla Hama Salih \\ Medical Laboratory \\ Technical College of Health \\ Sulaimani Polytechnic University \\ Sulaimani, Iraq \\ Mariwan.abdulla@spu.edu.iq
}

Muhammed Babakir-Mina

Medical Laboratory

Technical College of Health

Sulaimani Polytechnic University

Sulaimani, Iraq

m.babakir@spu.edu.iq

\begin{tabular}{|c|}
\hline Article Info \\
\hline $\begin{array}{l}\text { Volume } 5 \text { - Issue } 1 \text { - } \\
\text { June } 2020\end{array}$ \\
\hline $\begin{array}{l}\text { DOI: } \\
\text { 10.24017/science.2020.1.5 }\end{array}$ \\
\hline Article history: \\
\hline $\begin{array}{l}\text { Received } 25 \text { March } 2020 \\
\text { Accepted 14 May } 2020 \\
\end{array}$ \\
\hline Keywords: \\
\hline $\begin{array}{l}\text { Medication uses, medication } \\
\text { knowledge, medication } \\
\text { attitude, medication practice, } \\
\text { Sulaymaniyah province. } \\
\text { Kurdistan medication uses. }\end{array}$ \\
\hline
\end{tabular}

Article Info

Volume 5 - Issue 1 -

$10.24017 /$ science 2020.1 .5

Received 25 March 2020

Accepted 14 May 2020

Kurdistan medication uses.

\begin{abstract}
Drug uses is a multi-step process starting from consulting doctor, prescribing, ordering and using via individual either public or healthcare staff for therapeutic reasons. This process can be problematic for several reasons, especially in developing countries due to easily access to medications, self-diagnosis and people recommendation for certain cases. The aims of the present study were to assess the practice and attitude of medication uses and the knowledge about medication advantage and their risks by publics in Sulaymaniyah province. Then to build correlations between demographic characteristics and medication uses, in order to show the main impact of widely used medication on public health status. Finally, to provide community with statistical data about the level of knowledge, attitude and practice KAP in this region. The overall six hundred participant from the average of ten locations between governmental and privates hospitals and pharmacies as well as clinics were selected from central city and towns for data collection. The majority of participants were public from different background. The present study concluded that the 60 percentage of the participant were lack of adequate knowledge about the ability for differentiation between analgesic and antibiotic medications. The results of the current study showed inappropriate practices and attitudes that contribute to increasing health risks. It is also found that 72 percentage of participant who use prescription only drugs such as antibiotics can be possibly stopped after situation disappeared. This study also investigated several reasons for inappropriate practice, such as wrong believes with irregular consumption of medications, illiteracy, poor health services in terms of pharmacies and healthcare staff as well as easy access to most of the types of medications. Therefore, effort by governmental authorities is
\end{abstract}


urgent toward reducing the risk of the situation, and negative consequences regarding inappropriate practice toward patient care in the region.

\section{INTRODUCTION}

The process of regular usage of medications by patients is important to avoid any health consequences. The World Health Organization WHO reported that about 700000 people die each year globally, because of drug-resistant diseases. Medication use process can be directed by several factors, patient behavior, healthcare professionals. The appropriate use of medications help in effectiveness and safety of the medication use process [1]. The selfdiagnosis and self-discontinuation of medications could be among the factors of inappropriate use of medications[2]. In the past, researches about misuses of medication have been reported, the health consequence of antibiotic resistant bacteria were resulted from misused of antibiotic medications [3]. Outpatients are considered to be active receivers of drug therapy[4]. Patients' medication knowledge plays a crucial role in the disease management, as it was shown to be positively correlated with a higher quality of life, adherence to treatment, and attainment of favorable clinical outcomes [5]. Medication use is an action that involves a change in behavior, and appropriate use of medications by patients involves a desired change in behavior which is consistent with the prescription issued by physicians and/or recommendations by pharmacists. The attitude of medication uses by patient can be influenced by some factors, culture and religious believes are predominant factors especially in developing countries $[6$, 7]. Several reports all over the world studied the attitude of general public [8], student [2,9], adolescence [10], elderly [11, 12] and healthcare providers [11], but Sulaymaniyah public attitude were not studied yet. Herein, this study was conducted on Sulaymaniyah public to study or assess the knowledge, attitude and practice KAP of medication use and safety. Also the aim is to evaluate the causes of the obtained level of the attitude and knowledge and practice of medication uses and the consequent risks. Finally, this study aimed to differentiate the KAP between the general public inside and outside the Sulaymaniyah province.

\section{METHODS AND MATERIALS}

\section{Study design and population}

A cross-sectional study was carried out to assess the evaluation of knowledge, practice and attitude of medication among the general public in the Sulaymaniyah-Iraq during the period of study from 27 May to 27 August 2019. A number of hospitals in Sulaymaniyah city were included in this study and these hospitals work under the supervision of ministry of health/ Kurdistan regional government. The included hospitals Shar General Hospital, Internal Teaching Hospital, Surgery Teaching Hospital, Bakhshin general private hospital and also included same doctors private clinic and special pharmacies. Other hospitals outside Sulaymaniyah also included; Ranya General Hospital, Shaid Sarkawt Hospital in SeidSadiq, Shirwana Health Center in Kalar and Shahid Abdalrahim health center in Xalakan with many private doctors clinics at rural area.

\section{Inclusion and Exclusion criteria}

The current study included all patients and people with the patient in the mentioned hospitals in Sulaymaniyah city and physician private clinic and special pharmacy were 600 cases. Uncompleted form and unintentional completed forms were excluded. 


\section{Sample calculations and questionnaire form details}

The numbers of cases were determined by sample size calculation by Daniel's method. The questionnaire form was sourced from; studies about evaluation of knowledge, practice and attitude of medication among the general public. Furthermore, the questionnaire form was reviewed by academic experts in the Sulaymaniyah hospitals, Sulaimani Polytechnic University and Sulaimani University for validity of the questionnaire form. The questionnaire form was included questions on demographical information and general questions such as (age, gender, marital status, location, smoking, alcohol drink, occupation, family income, medical history, certificate degree and KAP questions). Assessment questions were the other section of the questionnaire form, were consists of three parts; the first part contains some questions about basic knowledge of the people about medications. The second part, consist of 10 questions on people's attitudes on medication and last part included questions about people's practices on medication use. Furthermore, assess questions were designed to avoid time-consuming and to get full attention of the respondent.

\section{Data collection and data analysis}

Data collection was performed by using questionnaire form and filled in by face to face method and responders have an opportunity to ask an explanation on the questions if they needed. Scores calculated based on each KAP parameters. Statistical analysis was done using SPSS program version 22, two approaches were used: descriptive approach for finding frequencies, percentages, means and standard deviation and constructing tables and figures; while analytical approach used for finding associations between variables and finding PValues; a P-value of $\leq 0.05$ was considered statistically significant. Chi square test was used for finding these associations.

\section{Ethical consideration}

This study was approved by the Ethical Committee at Sulaimani Polytechnic University/ Technical College of health and permission of general Sulaymaniyah directorate of Health and the in administrations of the hospitals that were included in this study.

\section{RESULTS}

The study consists of 600 participants from different areas with in Sulaymaniyah governorate. Study participants had gender distribution that female was $58.2 \%$ and male was $41.8 \%$. Their mean age was $42.28 \pm 13.48 \mathrm{SD}$ and $77 \%$ of them were married. The participants had different employment statuses. The results of distribution frequencies of all socio-demographic characteristics were shown in the Table 1.

Table 1: Study variables and frequencies of socio-demographic characteristic distribution

\begin{tabular}{llcc} 
Variables & & Frequencies & \% \\
\hline Gender & Male & 349 & 58.2 \\
& Female & 251 & 41.8 \\
\hline Marital status & & 129 & \\
& Single & 462 & 21.5 \\
& Married & 5 & 77.0 \\
& Divorced & 4 & 0.8 \\
& Widow & & 0.7 \\
\hline \multirow{2}{*}{ Occupation } & Governmental employee & 162 & 27.0 \\
& Self-employee & 166 & 27.7 \\
& Un-employed & 211 & 35.2 \\
& Retired & 32 & 5.3 \\
\hline
\end{tabular}




\begin{tabular}{llcc}
\hline & Student & 29 & 4.8 \\
& & & \\
\hline Residency & Sulaymaniyah city & & 60.0 \\
& Outside Sulaymaniyah city & 360 & 40.0 \\
\hline Family income & $\quad$ (500.000 IQD & 240 & 51.2 \\
& $\mathbf{5 0 0 . 0 0 0}-\mathbf{1 0 0 0 . 0 0 0}$ IQD & 307 & 37.2 \\
& $>\mathbf{1 0 0 . 0 0 0}$ IQD & 187 & 17.6 \\
\hline Smoking & Yes & 106 & 22.2 \\
& No & 133 & 66.8 \\
& Passive smoker & 401 & 11.0 \\
\hline Alcohol & Yes & 66 & 4.5 \\
& No & 27 & 91.5 \\
& On occasion & 549 & 4.0 \\
\hline \multirow{3}{*}{ Education level } & $\quad 24$ & \\
& $\quad$ Read \& write & & 42.7 \\
& High school \& diploma & 258 & 39.3 \\
& $\quad$ Graduate \& Postgraduate & 108 & 18.0 \\
& (From college and institutions ) & & \\
\hline
\end{tabular}

In this study about $45 \%$ of participants had chronic diseases, meanwhile $54 \%$ were found without chronic deseases as shown in figure 1. Results of the participants' responses for questions related to knowledge represented the followings: $16.5 \%$ recognise their medicnes by color. $29.2 \%$ of participant discontinue on anti-hypertensive drugs with improved symptoms. Attitude was evaluated by some questions. Out of 600 respondents, 226 (37.7\%) agreed that pharmacist provided enough information on drug use, reversly $288(48 \%)$ of participant claimed that pharmacists did not provide enough information on their medications. The attitude about using multivitamins without doctor prescriptions and with doctors prescriptions were $90.8 \%$ and $9.2 \%$ respectively. In question about drinking tea interfering with medications, majority of them $98.8 \%$ think drinking tea has no interfere with taking medications. Another important results about factors affect people and push them to use more medications are disease, low price, private hospital and numbers of pharmacies $(84.7 \%, 12 \%$, $1.8 \%, 1.5 \%$ respectively). The practice finding includes extensive use of antibiotics without prescriptions. Out of 600 participants 307(51.2\%), 152 (25.3\%) and 63(10.5\%) used antibiotic without prescription for common cold, gastro-enteritis and urinary tract infections respectively. Analgesic use during pain without prescription was 489(81.5\%). Majority of them used analgesic for headache 402(67.1) and back pain 120(20\%). The associations between knowledge, attitude, and practice of medication uses and gender, level of education, risedency, and types of diseases were showed in table 2 , table 3 , and table 4. 


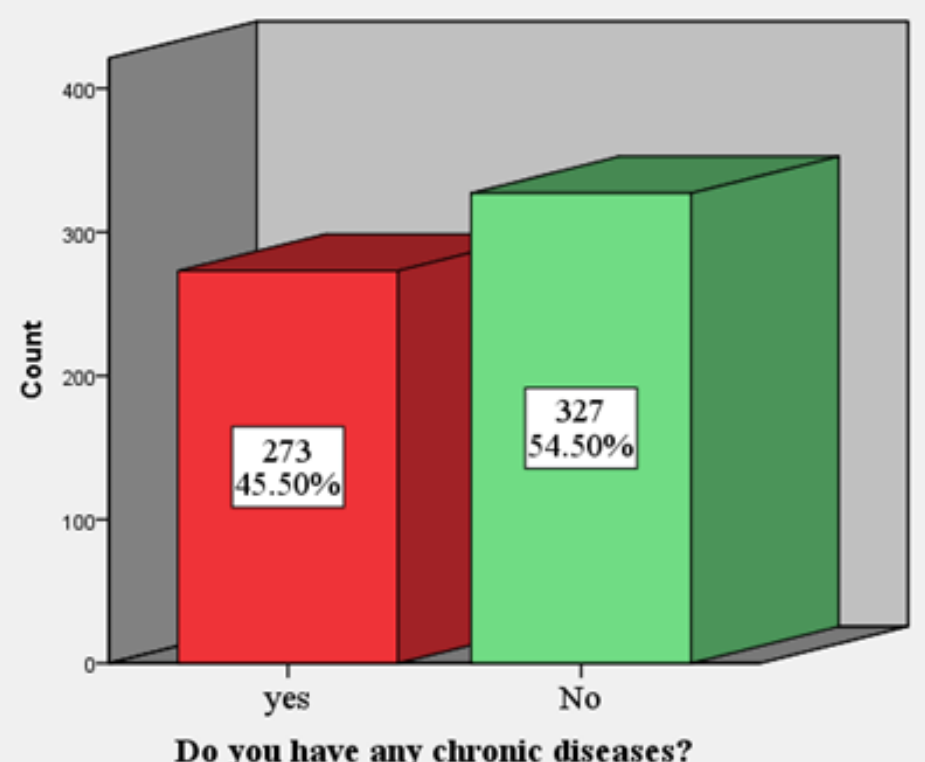

Do you have any chronic diseases?

Figure 1: Participant's chronic diseases

Table 2: Association between knowledge questions and residency

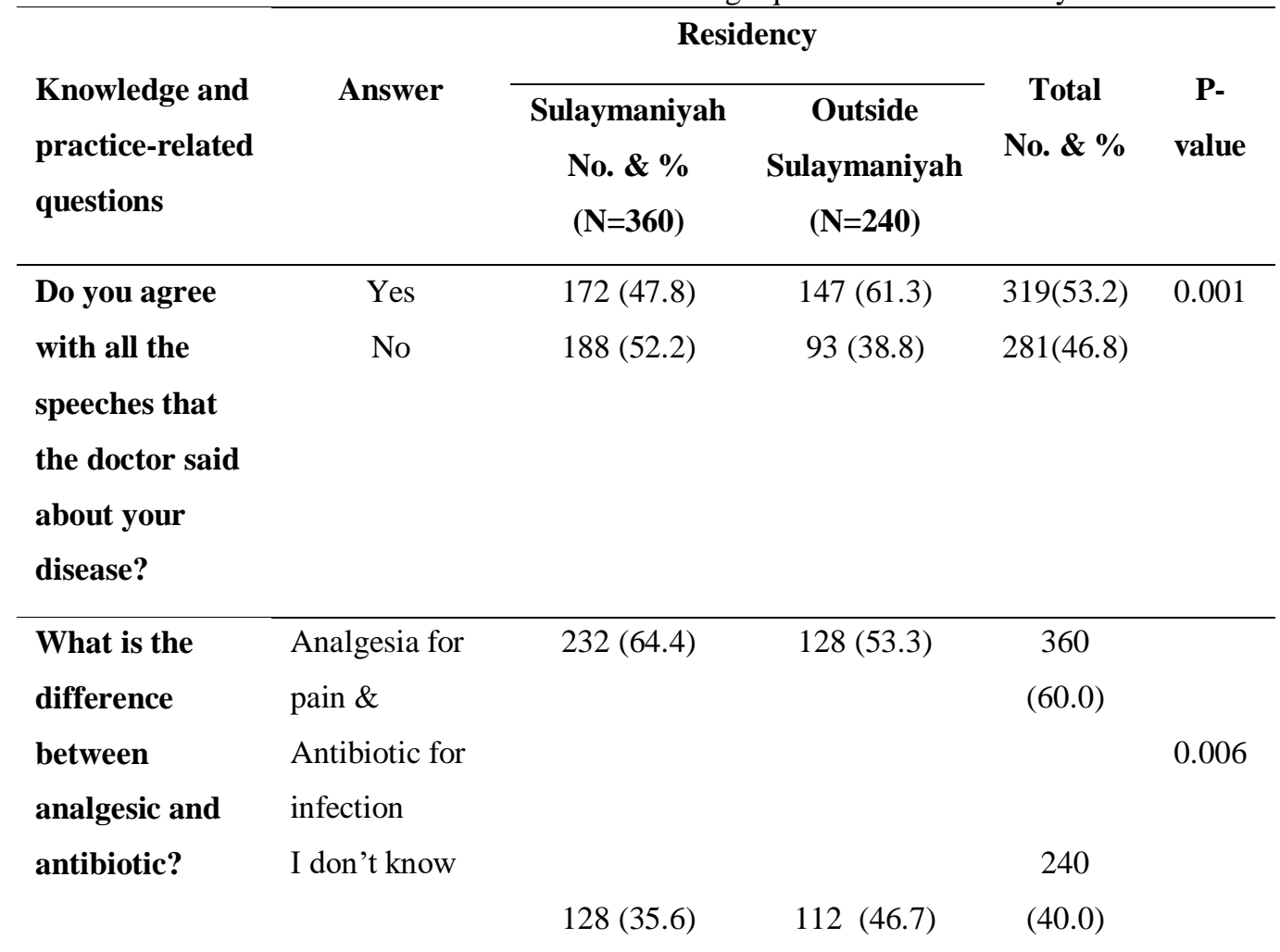




\begin{tabular}{|c|c|c|c|c|c|}
\hline \multirow{8}{*}{$\begin{array}{l}\text { What is your } \\
\text { main source of } \\
\text { information? }\end{array}$} & Doctor & $75(20.8)$ & 47 (19.6) & 122 & \multirow{8}{*}{$<0.001$} \\
\hline & Pharmacist & $11(3.1)$ & $4(1.7)$ & (20.3) & \\
\hline & Internet & $51(14.2)$ & $6(2.5)$ & $15(2.5)$ & \\
\hline & T.V & 57 (15.8) & $55(22.9)$ & $57(9.5)$ & \\
\hline & \multirow[t]{4}{*}{ Public } & \multirow[t]{4}{*}{$166(46.1)$} & \multirow[t]{4}{*}{$128(53.3)$} & 112 & \\
\hline & & & & (18.7) & \\
\hline & & & & 294 & \\
\hline & & & & $(49.0)$ & \\
\hline \multirow{7}{*}{$\begin{array}{l}\text { Do you think } \\
\text { that the } \\
\text { overuse of } \\
\text { paracetamol } \\
\text { will cause? }\end{array}$} & Liver toxicity & $49(13.6)$ & $18(7.5)$ & 67 (11.2) & \multirow{7}{*}{0.04} \\
\hline & Kidney & & & & \\
\hline & damage & $154(42.8)$ & $117(48.8)$ & 271 & \\
\hline & High Blood & & & $(45.2)$ & \\
\hline & Pressure & 77 (21.4) & $42(17.5)$ & $119(19.8)$ & \\
\hline & \multirow[t]{2}{*}{ Not of all } & \multirow[t]{2}{*}{$80(22.2)$} & \multirow[t]{2}{*}{$63(26.3)$} & 143 & \\
\hline & & & & $(23.8)$ & \\
\hline
\end{tabular}


Table 3: Association between gender and attitude and knowledge-related questions

\begin{tabular}{|c|c|c|c|c|}
\hline \multicolumn{2}{|l|}{ Knowledge and Attitude questions } & \multirow{2}{*}{$\begin{array}{r}\text { Gender } \\
\text { Male 'emale }\end{array}$} & \multirow[t]{2}{*}{ Total } & \multirow{2}{*}{ P-value } \\
\hline \multirow{5}{*}{$\begin{array}{l}\text { Anti-hypertensive drugs could be discontinued when blood } \\
\text { pressure returned to normal? }\end{array}$} & & & & \\
\hline & Yes & $\begin{array}{ll}111 \quad 64\end{array}$ & 175 & \multirow{4}{*}{0.094} \\
\hline & & $31.8 \% \quad 25.5 \%$ & $29.2 \%$ & \\
\hline & No & $238 \quad 187$ & 425 & \\
\hline & & $68.2 \% \quad 74.5 \%$ & $70.8 \%$ & \\
\hline \multirow[t]{4}{*}{ Can you differentiate between the drugs by its colors? } & Yes & $62 \quad 37$ & 99 & \multirow{4}{*}{0.325} \\
\hline & & $17.8 \% \quad 14.7 \%$ & $16.5 \%$ & \\
\hline & No & $287 \quad 214$ & 501 & \\
\hline & & $82.2 \% \quad 85.3 \%$ & $83.5 \%$ & \\
\hline \multirow{4}{*}{$\begin{array}{l}\text { You can discontinue the use of antibiotics by yourself when the } \\
\text { symptoms relieved? }\end{array}$} & Yes & $259 \quad 173$ & 432 & \multirow{4}{*}{0.155} \\
\hline & & $74.2 \% \quad 68.9 \%$ & $72.0 \%$ & \\
\hline & No & $90 \quad 78$ & 168 & \\
\hline & & $25.8 \% 31.1 \%$ & $28.0 \%$ & \\
\hline \multirow{4}{*}{$\begin{array}{c}\text { Vitamins are considered essential nutrients, so will not cause } \\
\text { negative effect }\end{array}$} & agree & 51 & 91 & \multirow{4}{*}{0.656} \\
\hline & & $14.6 \% \quad 15.9 \%$ & $15.2 \%$ & \\
\hline & disagree & $298 \quad 211$ & 509 & \\
\hline & & $85.4 \% \quad 84.1 \%$ & $84.8 \%$ & \\
\hline \multirow{4}{*}{$\begin{array}{l}\text { Do you ever taken less than the prescribed dose of your } \\
\text { medication? }\end{array}$} & Yes & 188 & 281 & \multirow{4}{*}{0.0001} \\
\hline & & $53.9 \% \quad 37.1 \%$ & $46.8 \%$ & \\
\hline & No & $161 \quad 158$ & 319 & \\
\hline & & $46.1 \% \quad 62.9 \%$ & $53.2 \%$ & \\
\hline \multirow{4}{*}{$\begin{array}{l}\text { Do you ever taken more than the prescribed dose of your } \\
\text { medication? }\end{array}$} & Yes & 29 & 39 & \multirow{4}{*}{0.034} \\
\hline & & $8.3 \% \quad 4.0 \%$ & $6.5 \%$ & \\
\hline & No & $320 \quad 241$ & 561 & \\
\hline & & $91.7 \% \quad 96.0 \%$ & $93.5 \%$ & \\
\hline \multirow[t]{4}{*}{ Do you ever used the medication without information? } & Yes & 23 & 48 & \multirow{4}{*}{0.02} \\
\hline & & $23.6 \% \quad 41.1 \%$ & $29.6 \%$ & \\
\hline & No & 81 & 114 & \\
\hline & & $76.4 \% \quad 58.9 \%$ & $70.4 \%$ & \\
\hline \multirow{4}{*}{$\begin{array}{l}\text { Do you ever taken medicines according to others } \\
\text { recommendation? }\end{array}$} & Yes & 135 & 254 & \multirow{4}{*}{0.03} \\
\hline & & $38.7 \% \quad 47.4 \%$ & $42.3 \%$ & \\
\hline & No & $214 \quad 132$ & 346 & \\
\hline & & $61.3 \% \quad 52.6 \%$ & $57.7 \%$ & \\
\hline \multirow{4}{*}{$\begin{array}{l}\text { Do you ever taken the doctor's prescribed medicine when } \\
\text { you had similar symptoms? }\end{array}$} & Yes & $\begin{array}{ll}116 & 105\end{array}$ & 221 & \multirow[t]{4}{*}{0.03} \\
\hline & & $33.2 \% \quad 41.8 \%$ & $36.8 \%$ & \\
\hline & No & $233 \quad 146$ & 379 & \\
\hline & & $66.8 \% \quad 58.2 \%$ & $63.2 \%$ & \\
\hline
\end{tabular}


Table 4: Associations between knowledge, attitude, and practice-related question with types of diseases

\begin{tabular}{|c|c|c|c|c|c|}
\hline \multirow{3}{*}{ Questions } & \multirow{3}{*}{ Answer } & \multirow{2}{*}{\multicolumn{2}{|c|}{ Type of the disease $(n=91)$}} & \multirow{3}{*}{ Total } & \multirow{3}{*}{ P-Value } \\
\hline & & & & & \\
\hline & & $\underset{n=72}{H T}$ & $\begin{array}{c}\text { DM } \\
n=19\end{array}$ & & \\
\hline $\begin{array}{l}\text { Can you differentiate } \\
\text { the drug by its color? }\end{array}$ & $\begin{array}{l}\text { Yes } \\
\text { No }\end{array}$ & $\begin{array}{l}29(40.3) \\
43(59.7)\end{array}$ & $\begin{array}{c}2(10.5) \\
17(89.5)\end{array}$ & $\begin{array}{l}31(34.1) \\
60(65.9)\end{array}$ & 0.01 \\
\hline $\begin{array}{l}\text { Antihypertensive drugs } \\
\text { could be discontinuing } \\
\text { when BP returns to } \\
\text { normal? }\end{array}$ & $\begin{array}{l}\text { Yes } \\
\text { No }\end{array}$ & $\begin{array}{l}11(15.3) \\
61(84.7)\end{array}$ & $\begin{array}{c}2(10.5) \\
17(89.5)\end{array}$ & $\begin{array}{c}13 \\
(114.3) \\
78(85.7)\end{array}$ & 0.45 \\
\hline $\begin{array}{l}\text { Can you discontinue } \\
\text { the use of antibiotics by } \\
\text { yourself when the } \\
\text { symptoms relieved? }\end{array}$ & $\begin{array}{l}\text { Yes } \\
\text { No }\end{array}$ & $\begin{array}{l}53(73.6) \\
19(26.4)\end{array}$ & $\begin{array}{c}18(94.7) \\
1(5.3)\end{array}$ & $\begin{array}{l}71(78 \%) \\
20(22 \%)\end{array}$ & 0.03 \\
\hline $\begin{array}{l}\text { Vitamins are } \\
\text { considered essential } \\
\text { nutrients, but } \\
\text { overusing will cause } \\
\text { negative effect }\end{array}$ & $\begin{array}{c}\text { Agree } \\
\text { Disagree }\end{array}$ & $\begin{array}{l}20(27.8) \\
52(72.2)\end{array}$ & $\begin{array}{c}8(42.1) \\
11(57.9)\end{array}$ & $\begin{array}{l}28(30.8) \\
63(69.2)\end{array}$ & 0.17 \\
\hline $\begin{array}{l}\text { Have you ever taken } \\
\text { medicine according to } \\
\text { others suggestion? }\end{array}$ & $\begin{array}{l}\text { Yes } \\
\text { No }\end{array}$ & $\begin{array}{l}49(68.1) \\
23(31.9)\end{array}$ & $\begin{array}{c}7(36.8) \\
12(63.2)\end{array}$ & $\begin{array}{l}56(61.5) \\
35(38.5)\end{array}$ & 0.01 \\
\hline Do you ever taken & Yes & $49(68.1)$ & $7(36.8)$ & $56(61.5)$ & 0.013 \\
\hline $\begin{array}{l}\text { medicines according to } \\
\text { others } \\
\text { recommendation? }\end{array}$ & No & $23(31.9)$ & $12(63.2)$ & $35(38.5)$ & \\
\hline
\end{tabular}

\section{DISCUSSION}

This study found that the observed gaps in knowledge that is statistically significant in terms of both medications use and safety. The lacks of enough knowledge that belong to the use of some medications without prescription were identified. This study demonstrated that participants believed that the medications that are known as prescription-only drugs such as anti-hypertensive drugs, antibiotics and analgesics can be possibility stopped when symptoms disappeared. Similar study were supported the result of this study [1-4]. The toxicity aspect of medication were explored in this study, significantly $(\mathrm{p}<0.01)$ the majority of participant were found without concern to the toxicity of the most used analgesic paracetamol concerning to liver toxicity, compared to other study related to paracetamol toxicity, low knowledge in Sulaymaniyah should be considered [5-6]. The participant responses from this study toward the fact of overuse of over the counter medicine like paracetamol cause negative consequenies, remain higher than the repoted results from different studies about the effect of paracetamol and consequences of overuse [7-8]. According to this study, the sources are 
public itself, doctors, T.V, internet and pharmacist respectively. This is inverse when compared to sources of drug information in other studies that were conducted in nearby countries and others [9-11]. An explanation for this result is accessibility of public to pharmacists and physicians in all country area, low levels of public education in reading drug leaflet that contain all relevant details about the drug. The absence of drug information center Sulaymaniyah might be contributed factor for inaccurate sources in medication information. Positive attitude was observed among population of Sulaymaniyah city. It was established that knowledge and attitude influence people behaviors and performance. As indicated by the hypothesis of contemplated activity, patients plan to lead conduct, for example, counsel with pharmacist about medication, just when they assess their attitude positively [12]. Meanwhile, $52.4 \%$ of the respondents strongly agree that doctor's discussion on their medications is not including enough information and clarification. As well as a gap is surely available in pharmacist's clarifications on their medication's use too by way that $62.3 \%$ of participants said not enough explanation on drug give to them in pharmacy niether by physician as well. Some researchers were studied the physician atttitude or behaviour toward medication use, it was believed that several factors direct physician to show poor attitude including poor facility available at their clinics, in adiquate salary and busy clinic during working hours [13-14]. Another attitude that confirmed in our work is that the participants think usage of multivitamins is simple issue and no need prescription. Several studies showed negative attitude and practice about use of multivitamins. Researchers in India [15] found that the use of multivitamins was highly prevalent among the public and most of them were unaware with their possible harm or interactions. In accordance with the latter finding, a considerable number of participants in both recent surveys had the belief that these drugs like food and unaware with the health hazards which may result as a consequence of their over consumptions. Best explanation for this attitude and practice are the advertisements and availability of these drugs as over-the-counter medicines are the major contributory factors that lead to these misconceptions. The average extensive use of medication such as antibiotics and there are several problems in practicing medication uses, for example extensive use of antibiotics without prescriptions and analgesics, incomplete use of pharmaceutical courses and doses, shared medicines with others, and use of medications based on other people suggestions are all considered to be serious practicing in Sulaymaniyah as shown in (Table 4). These results of this study also confirmed and found by other studies, for example high prevalence rates of antibiotic prescribing were identified. The results of the current study were similar to previous research from Italy, Syria and Jordan, [16-18] but different at some point when compared to Malaysia and European countries [19-20]. For example, the high rate of prescribing could relatively be demonstrated by the participant's agreement that doctors often prescribe an antibiotic because the patient expects and disagreement that doctors often take time to consider carefully whether antibiotics are needed or not. The over prescribing antibiotics by physician as a result of patient aggrements could be the main factor that contributing or developing antibiotic resistance [21]. This underscores the need for policies of auditing antibiotic prescriptions in the health care facilities of Sulaimani, and investigating the consultation behavior and other behavioral components engaged in patients' expectations for antibiotics. Self-medication can be a problem in many countries. The current study showed that over usage of medications by participant themselves without compelling indications, only based on other people and relatives' suggestions or someone used a drug that had good benefit from it and recommended to other to use it. Also, re-use of house stored medications and prescription drugs are common. This is the case in other countries, for example in Saudi Arabia about $43.5 \%$ of the home used medications were purchsed by the friends or relatives recommendations. Over $80 \%$ of thailand population were taken medcations without prescriptions for themselfes and the family members and even their relatives [22]. In a pilot study with small sample size interviewed at a local health center, $65 \%$ of the respondents used non-prescription drugs, while a community study in Thailand described the overuse of analgesics in rural communities [23-24]. Study in Sudan showed that $81.8 \%$ of Khartoum population provide medication without medical prescription, such as herbal remedies [25]. 
Another survey, conducted in Gezira State, found that all respondents had at least one pharmaceutical product stored at home, with around a half of all households reporting selfmedication, re-use of stored medicines and exchange of drugs between family members [26]. Repetition of the same drugs for the same symptoms or previous disease turned into identified as any other crucial misconception amongst the study participants. The effect of this practice is that, using the previously used drug might also mask the symptoms of the current illness and endanger the health of the patient. The availability of medicines free charge from governmental health facilities at all levels in the country may be a factor that leads to this malpractice. People should be educated on the way to properly deal with the leftover drugs of their houses. In a study performed in Malaysia $40 \%$ of the respondents suggested that they'll recommend to take their unused drug treatments to people who apparently experience similar symptoms [27]. The study showed that participant characteristics such as age and highest education level were correlated with the medication knowledge score and statistically significant ( $p$-value $<0.05$ ). Residency of participant have a great effect related to knowledge about differences between antibiotics and analgesics, paracetamol overdose and sources of drug information in which urban population have better knowledge compared to rural areas (p-value < 0.05). More studies needed for further investigation about the results. The literature reports variable findings as well [28].

\section{CONCLUSION}

The current study showed that there are lack of knowledge about adverse drug reactions among Sulaymaniyah public considering medication uses, and inappropriate practices and wrong attitudes which developing high risk on public health and consumption of large funds on medication uses. It is also investigated that several reasons for inappropriate practice, such as wrong believes with irregular consumption of medications, due to illiteracy, poor health services in terms of pharmacies and health staffs as well as easily access to obtain most of the types of medications. These results should be considered by governmental authorities to take steps toward reducing the risk of inappropriate of medication uses.

\section{REFERENCE}

[1] A. S. Eldalo, et al., "Saudi school students' knowledge, attitude and practice toward medicines," Saudi pharmaceutical journal : SPJ : the official publication of the Saudi Pharmaceutical Society, vol. 22, pp. 213-218, 2014.

[2] E. Ramia, et al., "Assessment of patients' knowledge and practices regarding their medication use and risks in Lebanon," Int J Clin Pharm, vol. 39, pp. 1084-1094, Oct 2017.

[3] A. Elbur, et al., "Knowledge, Attitudes and Practices on Medication Use and Safety among Saudi People: a Public -based Versus an Internet -based Survey in Taif; Kingdom of Saudi Arabia," S audi J. Med. Pharm. Sci, vol. 2, pp. 134-140, 06/01 2016.

[4] A. Mansouri, et al., "A review of medication errors in iran: sources, underreporting reasons and preventive measures," Iranian journal of pharmaceutical research : IJPR, vol. 13, pp. 3-17, Winter 2014.

[5] L. Hornsby, et al., "Survey of patient knowledge related to acetaminophen recognition, dosing, and toxicity," Journal of the American Pharmacists Association : JAPhA, vol. 50, pp. 485-9, 07/01 2010.

[6] N. Karami, et al., "Knowledge and attitude of analgesics use among Saudi population: A cross-sectional study," International Journal of Medical Science and Public Health, p. 1, 01/01 2018.

[7] C. T. Chambers, et al., "Self-administration of Over-the-counter Medication for Pain Among Adolescents," Archives of Pediatrics \& Adolescent Medicine, vol. 151, pp. 449455, 1997.

[8] R. J. Gilbertson, et al., "Paracetamol use, availability, and knowledge of toxicity among British and American adolescents," Arch Dis Child, vol. 75, pp. 194-8, Sep 1996. 
[9] U. Narhi, "Sources of medicine information and their reliability evaluated by medicine users," Pharm World Sci, vol. 29, pp. 688-94, Dec 2007.

[10] S. A. Alamri, et al., "Assessment of Drug Information Service in Public and Private Sector Tertiary Care Hospitals in the Eastern Province of Saudi Arabia," Pharmacy (Basel, Switzerland), vol. 5, p. 37, 2017.

[11] A. Cafege, "The Pharmacist as a Source of Drug Information," vol. 9, pp. 291-295, 1989.

[12] I. Ajzen and M. J. P. b. Fishbein, "Attitude-behavior relations: A theoretical analysis and review of empirical research," vol. 84, p. 888, 1977.

[13] I. O. Ajayi, et al., "Patient satisfaction with the services provided at a general outpatients' clinic, Ibadan, Oyo State, Nigeria," Afr J Med Med Sci, vol. 34, pp. 133-40, Jun 2005.

[14] L. Chen, et al., "Human resources for health: overcoming the crisis," Lancet, vol. 364, pp. 1984-90, Nov 27-Dec 32004.

[15] K. Sekhri and K. Kaur, "Public knowledge, use and attitude toward multivitamin supplementation: A cross-sectional study among general public," Int J Appl Basic Med Res, vol. 4, pp. 77-80, Jul 2014.

[16] F. Napolitano, et al., "Public Knowledge, Attitudes, and Experience Regarding the Use of Antibiotics in Italy," PLOS ONE, vol. 8, p. e84177, 2013.

[17] F. Barah and V. Goncalves, "Antibiotic use and knowledge in the community in Kalamoon, Syrian Arab Republic: a cross-sectional study," East Mediterr Health J, vol. 16, pp. 516-21, May 2010.

[18] M. Shehadeh, et al., "Knowledge, attitudes and behavior regarding antibiotics use and misuse among adults in the community of Jordan. A pilot study," Saudi Pharm J, vol. 20, pp. 125-33, Apr 2012.

[19] E. Commission, "Antimicrobial Resistance," Special Eurobarometer 407, 2013.

[20] A. Ling Oh, et al., "Public knowledge and attitudes towards antibiotic usage: a crosssectional study among the general public in the state of Penang, Malaysia," J Infect Dev Ctries, vol. 5, pp. 338-47, May 282011.

[21] B. E. Franco, et al., "The determinants of the antibiotic resistance process," Infection and drug resistance, vol. 2, pp. 1-11, 2009.

[22] H. S. Abou-Auda, "An economic assessment of the extent of medication use and wastage among families in Saudi Arabia and Arabian Gulf countries," Clin Ther, vol. 25, pp. 1276-92, Apr 2003.

[23] V. A. Prabhu, et al., "A survey on medicines safety and usage in community pharmacy," Journal of basic and clinical pharmacy, vol. 5, pp. 24-25, 2013.

[24] L. Sringernyuang, "Availability and use of medicines in rural Thailand," Academisch Proefschrift, University of Amsterdam, Netherlands, 2000.

[25] A. I. Awad, et al., "Self-medication practices in Khartoum State, Sudan," Eur J Clin Pharmacol, vol. 62, pp. 317-24, Apr 2006.

[26] M. A. Yousif, "In-home drug storage and utilization habits: a Sudanese study," East Mediterr Health J, vol. 8, pp. 422-31, Mar-May 2002.

[27] M. Hassali, et al., "A pilot study exploring awareness among general public toward issues related to medication safety in the state of Penang, Malaysia," Chronicles of Young Scientists, vol. 3, pp. 156-159, 07/18 2012.

[28] L. Leemans, et al., "Consumer study on the use of patient information leaflets," pp. 109$116,2011$. 